\title{
Clinical and Radiological Findings in Mayer-Rokitansky-Küster-Hauser Syndrome Type 2 \\ Case report
}

"Samih A. Odhaib, ${ }^{1}$ Miaad J. Mohammed, ${ }^{2}$ Ahmed J. H. Al-Ali, ${ }^{1}$ Abbas Ali Mansour ${ }^{1}$

\begin{abstract}
ABSTRAC T: Mayer-Rokitansky-Küster-Hauser syndrome (MRKHS) or Müllerian agenesis represents uterovaginal aplasia or hypoplasia of unknown aetiology in young women with usual 46,XX karyotype and normal secondary sexual characteristics. We report a 15-year-old female patient who presented to a specialised diabetes endocrine and metabolism centre in Basrah, Iraq, in 2019 with primary amenorrhoea and normal pubertal secondary sexual characteristics, hormonal workup and clinical examination. Abdominopelvic magnetic resonance imaging (MRI) revealed cervical and uterine agenesis with the absence of the proximal thirds of the vagina. Both kidneys were fused in the right iliac fossa with oval lobulated appearance and crossed fused ectopia. The ovaries were normal and located bilaterally. The diagnosis of MRKHS type 2 was confirmed based on clinical, biochemical and radiological findings. The correct clinical and radiological diagnosis of MRKHS by MRI is crucial for long-term management.
\end{abstract}

Keywords: Müllerian Aplasia; Case Report; Iraq

$\mathrm{T}$ HE MAYER-ROKITANSKY-KÜSTER-HAUSER syndrome (MRKHS) represents uterovaginal aplasia or hypoplasia in young women with a usual karyotype. ${ }^{1}$ The documented incidence is $1 / 4,000-5,000$ female births. Primary amenorrhoea is the presenting symptom despite the development of typical secondary sexual characteristics. ${ }^{2}$

The syndrome may be identified incidentally during the first sexual experience by a failure to achieve normal vaginal intercourse. Recurrent abdominal pain, because of rudimentary uterine parts at the time of the presumed menstrual cycle (cryptomenorrhea) is an uncommon manifestation. ${ }^{3}$ There are two distinct types of MRKHS: type 1 which is typical MRKHS with uterovaginal aplasia and type 2 which is atypical MRKHS that is additionally associated with systemic congenital anomalies of different penetrance. ${ }^{4} \mathrm{MRKHS}$ does not present with clearly identifiable genetic causes although familial clustering of the syndrome is seen. ${ }^{5}$ Genetic and environmental dynamics may add to the development of MRKHS although their specific contribution is often unknown. ${ }^{1}$

The patient history, clinical examination, ultrasound, magnetic resonance imaging (MRI) and laparoscopy can assist in the initial diagnosis of MRKHS. ${ }^{6}$ The main focus of management is to correct vaginal agenesis through several surgical and nonsurgical techniques.

\section{Case Report}

A 15-year-old female patient presented to a specialised diabetes endocrine and metabolism centre in Basrah, Iraq, in 2019 with primary amenorrhoea. She had normal pubertal secondary sexual characteristics; axillary and pubic hair growth started at the age of 13-14 years. She described usual breast development for her age. She had no history of vaginal bleeding, discharge or intermittent pelvic pain. She was indifferent to her amenorrhea and satisfied with her body image. Her mother and two sisters had their menarche at 13 and 14 years, respectively, and there was no history of amenorrhoea among the first and second-degree relatives. Other parts of the history were noncontributory.

One month before the patient presented to the clinic, she had consulted a gynaecologist who undertook some hormonal and general investigations, including an ultrasonographic evaluation that failed to visualise the uterus [Table 1]. This finding urged the family to seek a second opinion.

On current examination, it was found that the patient was a lean adolescent with no apparent dysmorphic features and had normal vital signs. Her weight was $56.5 \mathrm{~kg}$, her height was $1.64 \mathrm{~m}$ and she had a body mass index of $21 \mathrm{~kg} / \mathrm{m}^{2}$. The cardiorespiratory examination was routine. Abdominal examination, after the complete evacuation of the bladder, was 
Table 1: Results of different investigations performed one month before presentation of a 15-year-old female patient with MayerRokitansky-Küster-Hauser Syndrome type 2

\begin{tabular}{|c|c|c|}
\hline Investigation & Patient's result* & $\begin{array}{c}\text { Reference } \\
\text { range }^{*}\end{array}$ \\
\hline $\mathrm{FSH}$ in $\mathrm{mIU} / \mathrm{mL}$ & $\begin{array}{c}2.8 \\
(2.8 \mathrm{IU} / \mathrm{L})\end{array}$ & $\begin{array}{c}1.5-12.4 \\
(1.5-12.4 \mathrm{IU} / \mathrm{L})\end{array}$ \\
\hline $\mathrm{LH}$ in $\mathrm{mIU} / \mathrm{mL}$ & $\begin{array}{c}1 \\
(1 \mathrm{IU} / \mathrm{L})\end{array}$ & $\begin{array}{c}1-18 \\
(1-18 \text { IU/L) }\end{array}$ \\
\hline Prolactin in $\mu g / L$ & $\begin{array}{c}15 \\
(652.17 \mu \mathrm{IU} / \mathrm{L})\end{array}$ & $\begin{array}{c}4-30 \\
(85.1064 \mu \mathrm{IU} / \mathrm{L})\end{array}$ \\
\hline DHEA-S in $\mu \mathrm{g} / \mathrm{dL}$ & $193(5.21 \mu \mathrm{mol} / \mathrm{L})$ & $\begin{array}{c}145-395 \\
(4-10.7 \mu \mathrm{mol} / \mathrm{L})\end{array}$ \\
\hline Cortisol in $\mu \mathrm{g} / \mathrm{dL}$ & $\begin{array}{c}13 \\
(358.64 \mathrm{nmol} / \mathrm{L})\end{array}$ & $\begin{array}{c}5-25 \\
(138-690 \mathrm{nmol} / \mathrm{L})\end{array}$ \\
\hline $\mathrm{ACTH}$ in $\mathrm{pg} / \mathrm{mL}$ & $\begin{array}{c}25 \\
(5.5 \mathrm{pmol} / \mathrm{L})\end{array}$ & $\begin{array}{c}10-60 \\
(2.2-13.2 \mathrm{pmol} / \mathrm{L})\end{array}$ \\
\hline $\mathrm{E} 2$ in $\mathrm{pg} / \mathrm{mL}$ & $\begin{array}{c}22 \\
(80.76 \mathrm{pmol} / \mathrm{L})\end{array}$ & $\begin{array}{c}21-136 \\
(77-499 \mathrm{pmol} / \mathrm{L})\end{array}$ \\
\hline $17-\mathrm{OHP}$ in $\mathrm{ng} / \mathrm{dL}$ & 105 & $<200$ \\
\hline $\mathrm{TSH}$ in $\mathrm{ng} / \mathrm{mL}$ & 0.9 & $0.27-4.2$ \\
\hline $\mathrm{TT}$ in $\mathrm{ng} / \mathrm{dL}$ & $\begin{array}{c}17 \\
(0.59 \mathrm{nmol} / \mathrm{L})\end{array}$ & $\begin{array}{c}15-46 \\
(0.27-1.5 \mathrm{nmol} / \mathrm{L})\end{array}$ \\
\hline $\mathrm{AMH}$ in $\mathrm{pmol} / \mathrm{L}$ & $\begin{array}{c}1.83 \\
(13.1 \mathrm{pmol} / \mathrm{L})\end{array}$ & $\begin{array}{c}>1.0 \\
(>7.14 \mathrm{pmol} / \mathrm{L})\end{array}$ \\
\hline $\begin{array}{l}\text { Complete blood } \\
\text { picture and film }\end{array}$ & Normal & - \\
\hline $\begin{array}{l}\text { Anti-tissue } \\
\text { transglutaminase } \\
\text { IgA subtype in U/ } \\
\text { mL }\end{array}$ & 1.2 & $<3$ \\
\hline $\begin{array}{l}\text { Abdominopelvic } \\
\text { ultrasound study }\end{array}$ & $\begin{array}{l}\text { - Malrotated kidney } \\
\text { - Non-visualised uterus } \\
\text { - Normal ovaries }\end{array}$ & - \\
\hline
\end{tabular}

$F S H=$ follicular stimulating hormone; $L H=$ luteinising hormone; $D H E A-S=$ dehy droepiandrosterone sulphate; $A C T H=$ adrenocorticotrophic hormone; E2 = estradiol; $17-O H P=17$-hydroxyprogesterone; TSH = thyroid stimulating hormone; TT = total testosterone; $A M H=$ anti-Müllerian hormone; $I g=$ immunoglobulin

"The values in parentheses are the conversion of patient's results and reference ranges into SI units. normal apart from fullness at the suprapubic area with a centrally located fixed mass $(9 \times 9 \mathrm{~cm})$; the examination revealed a failure to palpate both kidneys.

Breast examination revealed Tanner stage 5 for both breasts, which was typical for her age. There were normal scalp and axillary hair densities and no acne. The patient was Caucasian and had fair skin with no abnormal discolouration. A fellow gynaecologist examined the pubic area and revealed normal external genitalia, normal clitoris and pubic hair distribution at Tanner stage 3.

A new transabdominal ultrasound study revealed a centrally located pelvic kidney and two normal ovaries with uterine agenesis. The radiologist advised an MRI study for confirmation [Figure 1]. The diagnosis of MRKHS type 2 was confirmed based on clinical, biochemical and radiological findings. The patient and the family inquired about the syndrome, progression, future management and sexual activity.

Additional workup included a cardiologist consultation (which ruled-out any possible associated hidden cardiac defects), an expert surgical opinion about possible surgical management and a psychiatric evaluation. The chromosomal karyotype revealed a normal female genotype of 46,XX. In early 2020, the patient's family requested a complete and detailed official report of her condition for a possible second expert surgical opinion.

An informed consent for publication and sharing of the data was granted by the patient's parents, with the full confidentiality for her identity.

\section{Discussion}

MRKHS carries complex clinical heterogeneity and genetic basis in most cases due to no family history
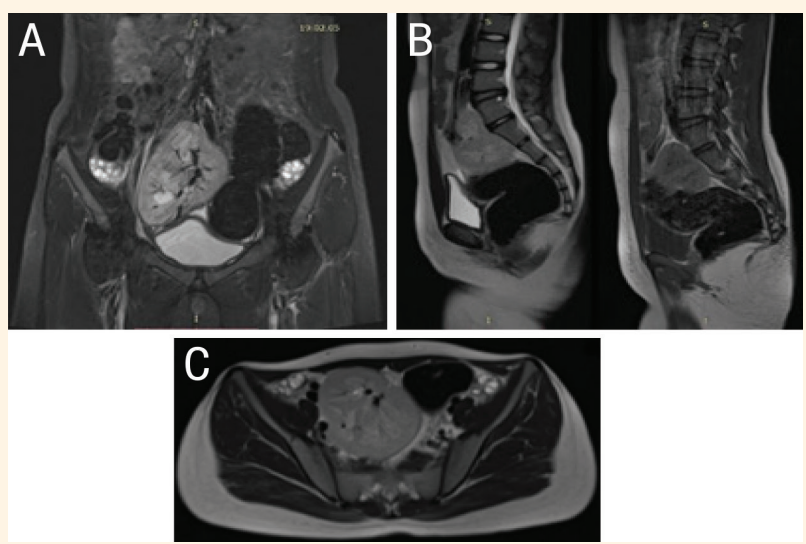

Figure 1: T2-weighted magnetic resonance images of a 15-year-old female patient. A: Coronal view showing the presence of bilateral normal-sized ovaries; both kidneys are fused in the right iliac fossa with an oval lobulated appearance and there is crossed fused ectopia of the kidneys. B: Axial view showing the crossed fused ectopia that appears as a midline mass; ovaries are normal and bilaterally located. C: Sagittal view showing complete uterine body and cervical agenesis with the absence of the proximal third of the vagina, leaving a short vagina $(22 \mathrm{~mm})$. 
of MRKHS in most cases. ${ }^{1,2}$ Different studies have described a wide range of MRKHS-associated malformations, such as renal malformations (34$58 \%)$, skeletal malformations $(12-50 \%)$ and cardiac malformations $(1-3.6 \%){ }^{1-4,8,9}$ The difference in the incidence of malformation is affected by the number of cases chosen with most studies being single-centre. ${ }^{6}$ The incidence of renal malformations in MRKHS is higher than that of the general population due to the association and interaction of the two ductal systems in utero. ${ }^{9}$

Normal androgen levels can usually be seen in women with type 1 (typical) MRKHS along with normal urinary excretion of steroid metabolites. ${ }^{4}$ However, women with MRKHS can have polycystic ovarian changes with associated hyperandrogenism and may even develop ovarian malignancy, although this is rare. ${ }^{2-5,10}$ Patients with type 2 (atypical) MRKHS may have gonadal dysgenesis or ectopic ovaries in the absence of other associated systemic malformations. ${ }^{6,711}$ Chromosomal aberrations may present in women with either type of MRKHS and has been seen in 1.4-4\%, contradicting the usual karyotype definition in the syndrome. ${ }^{2,3}$

In the current patient, the distal third of the vagina was present with cervical and uterine agenesis. A large Chinese cohort study showed a highly variable phenotype of MRKHS where all 594 patients showed complete vaginal atresia and cervical aplasia. However, it was found that $1-3 \mathrm{~cm}$ of the lower vagina may be present in women with MRKHS. ${ }^{6}$

The diagnosis of MRKHS relies on non-invasive methods. Transabdominal ultrasonography is a useful first investigation in suspected patients. Abdominopelvic MRI provides a more precise diagnosis when ultrasonographic findings are unclear. The addition of laparoscopy aids in the final diagnosis of MRKHS, especially in cases of a rudimentary uterus, although the American College of Obstetricians and Gynecologists recommends against it. ${ }^{12,13}$ The differential diagnosis of MRKHS includes vaginal structural anomalies such as congenital vaginal agenesis, low transverse vaginal septum and imperforate hymen. The 46,XY chromosomal aberration syndromes may be considered in the differential diagnosis. ${ }^{13}$

The main focus during the management of MRKHS, through surgical and nonsurgical techniques, is on improving sexual activity through the creation of a neovaginal and vaginal elongation, which alleviates some of the psychological burden and feelings of inferiority resulting from the fact that the female patient is devoid of the vagina.,12 Patients with MRKHS may require a sophisticated, custom-made and multidisciplinary approach to treatment through gynaecological, endocrinological and surgical care. Psychomental and sexual healthcare should be offered through counselling and peer support groups along with specialised sex and relationship therapy to promote high levels of sexual well-being. ${ }^{13,14}$

\section{Conclusion}

The correct diagnosis of MRKHS and its associated malformations is the most crucial step in active management. MRI can provide a precise diagnosis in most cases of MRKHS, whether type 1 or 2 , as was seen in the current case.

\section{AUTHORS' CONTRIBUTION}

SAO and AJHA managed the patients comprehensively. MJM performed and interpreted the images. AAM supervised the study process and provided logistical support. All authors have critically reviewed and approved the final draft and are responsible for the content and similarity index of the manuscript.

\section{References}

1. Herlin M, Bjørn AMB, Rasmussen M, Trolle B, Petersen MB. Prevalence and patient characteristics of Mayer-RokitanskyKüster-Hauser syndrome: A nationwide registry-based study. Hum Reprod 2016; 31:2384-90. https://doi.org/10.1093/ humrep/dew220.

2. Rall K, Eisenbeis S, Henninger V, Henes M, Wallwiener D, Bonin $\mathrm{M}$, et al. Typical and atypical associated findings in a group of 346 patients with Mayer-Rokitansky-Kuester-Hauser syndrome. J Pediatr Adolesc Gynecol 2015; 28:362-8. https:// doi.org/10.1016/j.jpag.2014.07.019.

3. Kapczuk K, Iwaniec K, Friebe Z, Kędzia W. Congenital malformations and other comorbidities in 125 women with Mayer-Rokitansky-Küster-Hauser syndrome. Eur J Obstet Gynecol Reprod Biol 2016; 207:45-9. https://doi.org/10.1016/j. ejogrb.2016.10.014.

4. McGowan R, Tydeman G, Shapiro D, Craig T, Morrison N, Logan $\mathrm{S}$, et al. DNA copy number variations are important in the complex genetic architecture of müllerian disorders. Fertil Steril 2015; 103:1021-30. https://doi.org/10.1016/j. fertnstert.2015.01.008.

5. Rall K, Conzelmann G, Schäffeler N, Henes M, Wallwiener D, Möhrle M, et al. Acne and PCOS are less frequent in women with Mayer-Rokitansky-Küster-Hauser syndrome despite a high rate of hyperandrogenemia: A cross-sectional study. Reprod Biol Endocrinol 2014; 12:23. https://doi.org/10.1186/1477-7827-12-23.

6. Pan HX, Luo GN. Phenotypic and clinical aspects of MayerRokitansky-Küster-Hauser syndrome in a Chinese population: An analysis of 594 patients. Fertil Steril 2016; 106:1190-4. https://doi.org/10.1016/j.fertnstert.2016.06.007.

7. Preibsch H, Rall K, Wietek BM, Brucker SY, Staebler A, Claussen $\mathrm{CD}$, et al. Clinical value of magnetic resonance imaging in patients with Mayer-Rokitansky-Kuster-Hauser (MRKH) syndrome: Diagnosis of associated malformations, uterine rudiments and intrauterine endometrium. Eur Radiol 2014; 24:1621-7. https://doi.org/10.1007/s00330-014-3156-3. 
8. Oppelt P, Renner SP, Kellermann A, Brucker S, Hauser GA, Ludwig KS, et al. Clinical aspects of Mayer-Rokitansky-KuesterHauser syndrome: Recommendations for clinical diagnosis and staging. Hum Reprod 2006; 21:792-7. https://doi.org/10.1093/ humrep/dei381.

9. Oppelt PG, Lermann J, Strick R, Dittrich R, Strissel P, Rettig I, et al. Malformations in a cohort of 284 women with MayerRokitansky-Küster-Hauser syndrome (MRKH). Reprod Biol Endocr 2012; 10:57-64. https://doi.org/10.1186/1477-7827-10-57.

10. Villa R, Azzollini J, Peissel B, Manoukian S. Co-occurrence of Mayer-Rokitansky-Küster-Hauser syndrome and ovarian cancer: A case report and review of the literature. Gynecol Onco Rep 2019; 28:68-70. https://doi.org/10.1016/j.gore.2019.03.010.

11. Kebaili S, Chaabane K, Mnif MF, Kamoun M, Kacem FH, Guesmi N, et al. Gonadal dysgenesis and the Mayer-RokitanskyKuster-Hauser syndrome in a girl with a 46, XX karyotype: A case report and review of literature. Indian J Endocrinol Metab 2013; 17:505-8. https://doi.org/10.4103/2230-8210.111663.
12. Takahashi K, Nakamura E, Suzuki S, Shinoda M, Nishijima Y, Ohnuki Y, et al. Laparoscopic Davydov procedure for the creation of a neovagina in patients with Mayer-RokitanskyKuster-Hauser syndrome: Analysis of 7 cases. Tokai J Exp Clin Med 2016; 20; 41:81-7.

13. Committee on Adolescent Health Care. ACOG Committee Opinion No. 728: Müllerian agenesis: Diagnosis, management, and treatment. Obstet Gynecol 2018; 131:e35-42. https://doi. org/10.1097/AOG.0000000000002458.

14. Fliegner M, Krupp K, Brunner F, Rall K, Brucker SY, Briken $\mathrm{P}$, et al. Sexual life and sexual wellness in individuals with complete androgen insensitivity syndrome (CAIS) and MayerRokitansky-Küster-Hauser Syndrome (MRKHS). J Sex Med 2014; 11:729-42. https://doi.org/10.1111/jsm.12321. 